\title{
OPTICAL AND ELECTRICAL PROPERTIES OF GRAPHITE THIN FILMS PREPARED BY DIFFERENT METHODS
}

\author{
Mykhailo M. Solovan,*, H.M. Yamrozyk ${ }^{\mathrm{a}}$, Viktor V. Brus ${ }^{\mathrm{b}}$, Pavlo D. Maryanchuk ${ }^{\mathrm{a}}$ \\ ${ }^{a}$ Yuriy Fedkovych Chernivtsi National University, st. Kotsyubyns'kogo 2, 58012, Chernivtsi, Ukraine \\ ${ }^{b}$ Nazarbayev University, 53 Kabanbay Batyr, 010000, Nur-Sultan City, Kazakhstan \\ *Corresponding Author: m.solovan@chnu.edu.ua \\ Received September 21, 2020; revised October 13, 2020; accepted October 16, 2020
}

The paper reports on the structural, optical and electrical properties of graphite thin films prepared by two methods: the vacuum-free method "Pencil-on-semiconductor" and via the electron beam evaporation such studies are of great importance for the further development of high-efficiency devices based on heterojunctions for electronics and optoelectronics. Graphite thin films prepared by the non-vacuum method has annealed at a temperature of 920K.The transmission spectra of the investigated graphite films and the electrical properties of these thin films were measured at $\mathrm{T}=300 \mathrm{~K}$. The value of the height of potential barriers $E_{b}$ at the grain boundaries and the temperature dependence of the electrical conductivity in the range $\ln \left(\sigma \cdot T^{1 / 2}\right)=f\left(10^{3} / T\right)$ were determined, It is established that the height of the potential barrier at the grain boundaries for the drawn graphite films is $E_{b}=0.03 \mathrm{eV}$, for annealed $E_{b}=0.01 \mathrm{eV}$ and for the graphite films deposited by the electron beam evaporation $E_{b}=0.04 \mathrm{eV}$, ie for annealed film the barrier height is the smallest. It is shown that graphite films deposited by the electron beam evaporation reveals the highest transmittance (T550 $\approx 60 \%$ ), and the transmission of drawn films is the lowest, annealing leads to its increase. The minimum values of transmission at a wavelength $\lambda=250 \mathrm{~nm}$ are due to the scattering of light at the defects that are formed at the grain boundaries. Annealed graphite films have been found to possess the best structural perfection because they have the lowest resistivity compared to non-annealed films and electron-beam films and have the lowest barrier height. Simultaneous increase of transmission in the whole spectral range, increase of specific electrical conductivity and decrease of potential barrier at grain boundaries of the annealed drawn graphite film clearly indicate ordering of drawn graphite flakes transferred onto a new substrate, which led to the reduction of light scattering and the improvement of charge transport due to the larger area of overlap between graphite flakes.

KEY WORDS: "pencil-on-semiconductor", annealing, thin films, graphite, grain boundaries

В останні роки невпинно збільшується інтерес науковців до методів отримання тонких вуглецевих шарів. Вуглець - це унікальний елемент, який відрізняється від інших елементів здатністю утворювати кристалічні структури із різним типом зв язку [1-3]. Серед усіх відомих форм вуглецю тонкі плівки графіту займають важливе місце завдяки своїм особливостям [4,5]. Можливість застосування тонких плівок графіту для виготовлення різних приладів електроніки та оптоелектроніки обумовлена їх унікальними властивостями: хорошою електропровідністю, високою рухливістю носіїв заряду при кімнатній температурі, прозорістю, хорошими механічними властивостями [1,2].

Вакуумні методи напилення тонких плівок графіту потребують використання інертних газів і $є$ досить складними для напилення плівок. Тому в останні роки науковців почали більше цікавити безвакуумні методи отримання тонких плівок, найдешевшим з яких для виготовлення плівок графіту виявився метод «олівець-нанапівпровіднику» [3]. Незважаючи на недолік даного методу, який полягає у необхідності грубої механічної або хімічної обробки поверхні підкладки для формування іiі шороховатості (необхідної для рисування плівки олівцем), запропонований метод має низьку вартість та є екологічно безпечним.

Плівки графіту вже успішно використовуються для створення гетероструктур типу діодів Шотткі, які можна використовувати в якості фотодіодів та детекторів ультрафіолетового випромінювання [6,7]. Підвищення ефективності таких фотоприймачів безпосередньо пов'язано з підвищенням якості вихідних матеріалів для створення гетероструктур та розумінням їх фізичних властивостей.

Мало робіт присвячено результатам комплексних експериментальних досліджень оптичних та електричних властивостей плівок графіту отриманих різними методами. Але такі дослідження мають велике значення для подальшої розробки високоефективних приладів на основі гетеропереходів для електроніки і оптоелектроніки [8,9].

В даній роботі проводяться дослідження структурних, оптичних та електричних властивостей тонких плівок графіту, виготовлених нами методом «олівець-на-напівпровіднику», а потім відпалених для покращення їх параметрів, та методом електронно-променевого випаровування для порівняння.

\section{ЕКСПЕРИМЕНТАЛЬНА ЧАСТИНА}

Тонкі плівки графіту виготовлені безвакуумним методом «олівець-на-напівпровіднику» та методом електронно-променевого випаровування. Відповідно до методу «олівець-на-напівпровіднику» [3] одна 3 поверхонь свіжосколотої монокристалічної соляної підкладки $(\mathrm{NaCl})$ механічно шліфувалася до шорсткості $\mathrm{R}_{\mathrm{a}}=0,2$ мкм, $\mathrm{R}_{\mathrm{z}}=0,23$ мкм та $\mathrm{R}_{\max }=1,1$ мкм. Однорідну графітову плівку рисували на підготовленій поверхні соляної підкладки за допомогою чистого графітового стержня (1 мм у діаметрі) при постійній силі притискання в 1 Н. Далі зразок обережно розміщували на поверхні дистильованої води плівкою графіту зверху. Соляна (C) M.M. Solovan, H.M. Yamrozyk, V.V. Brus, P.D. Maryanchuk, 2020 
підкладка повністю розчинялася за певний час і отримували нарисовану тонку плівку графіту, яка плавала на поверхні води. Плаваючу намальовану плівку графіту переносили на кварцову підкладку типорозміром $10 \times 10 \times 0,5$ мм. Після перенесення плівку висушували у потоці гарячого повітря $(350 \mathrm{~K})$ для видалення залишків води та формування якісного оптичного контакту з гладкою поверхнею підкладки. Відпал отриманих тонких плівок графіту проводили протягом 5 годин при температурі 920 К у вакуумі в електропечі СНОЛ $15 / 13003$ мікропроцесорним регулятором температури типу RT26-S765. Товщина нарисованих плівок становила 150 нм (товщину вимірювали за допомогою Мікроінтерферометра МИИ-4).

Також було напилено плівку графіту на кварцову підкладку розміром $10 \times 10 \times 0,5$ мм методом електроннопроменевого випаровування в універсальній вакуумній установці Leybold-Heraeus L560 із спресованих таблеток порошку графіту за температури підкладок 920 К. Потужність випаровуча становила 40 \% від максимального значення. Час напилення тривав 1-2 хв. Сформовані таблетки графіту розміщували в мідному тиглі 3 водяним охолодженням i поступово прогрівали електронним променем у вакуумній камері, яка відкачувалася турбомолекулярним насосом до вакууму $5 \cdot 10^{-5}$ мбар. Щоб запобігти випаровуванню забруднень 3 поверхні на початковому етапі підігріву таблеток заслінка між тиглем і підкладками була закрита. Товщина напилених плівок становила 30 нм.

Варто відзначити, що температура відпалу і температура напилення тонких плівок графіту методом електронно-променевого випаровування обиралася однаковою $(920 \mathrm{~K})$ для порівняння. Відповідно, до наших попередніх досліджень, це оптимальна температура для отримання полікристалічних плівок графіту.

Потужність електронного променю, товщину та швидкість напилення плівки контролювали за допомогою контролера напилення тонких плівок INFICON XTC. Перед напиленням таблетки графіту підігрівали, для запобігання інтенсивному газуванню порошку графіту у разі його різкого нагрівання. Температуру підкладок контролювали системою термопар у вакуумній камері і задавали за допомогою контролера на панелі управління.

Дослідження морфології поверхні тонких плівок графіту проводили за допомогою електронного скануючого електронного мікроскопа (CEM) Hitachi S-4100.

Спектри раманівського розсіювання вимірювали за допомогою раманівського мікроскопа LabRAM при довжині хвилі лазерного випромінювання 632,82 нм.

Спектри пропускання напилених та відпалених тонких плівок графіту вимірювали за допомогою спектрофотометра СФ-2000. Експериментальні точки знімалися в області довжин хвиль 200 - 1200 нм 3 кроком $1 \mathrm{HM}$.

Вимірювання температурної залежності електричного опору досліджуваних тонких плівок графіту проведені шляхом вимірювання струму, який проходив через зразок при прикладеній напрузі у 10 В. Контроль температури зразка здійснювали за допомогою мідь-константанової термопари. Нагрівання зразка здійснювали електричною пічкою, яка живилася від джерела стабілізованої напруги. Для підтримки постійної температури зразка використовувався терморегулятор.

\section{РЕЗУЛЬТАТИ ТА ОБГОВОРЕННЯ \\ Структурні властивості тонких плівок графіту}

На рис. 1. показано СЕМ зображення поверхні і поперечного перерізу двох тонких плівкок графіту, а саме: нарисованої плівки графіту та відпаленої при 920 К та отриманої методом електронно-променевого випаровування при температурі підкладки 920 К.

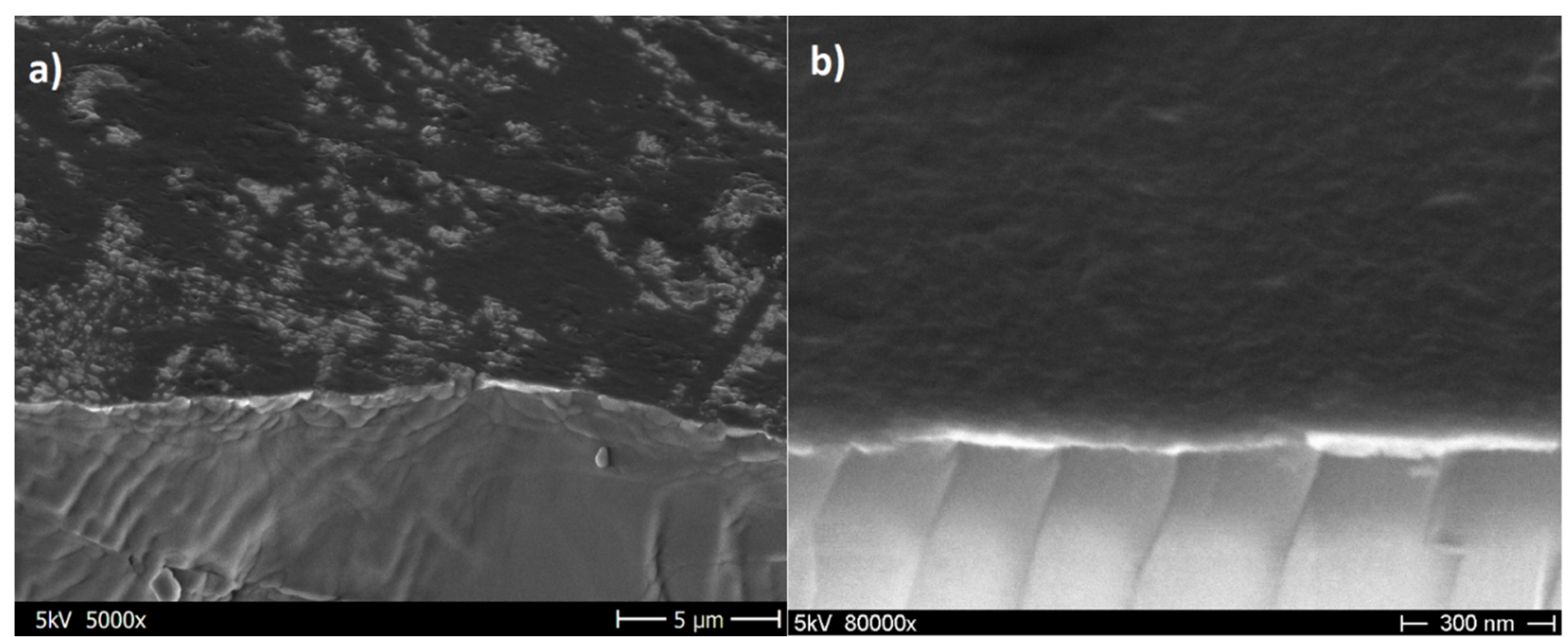

Рис. 1. СЕМ-зображення тонких плівок графіту виготовлених різними методами а) - нарисована плівка графіту, б) - плівка виготовлена методом електронно-променевого випаровування. 
Поверхня нарисованої плівки графіту має видимі отвори (рис. 1а), що є небажаним при виготовленні високоякісних електричних контактів, а поверхня тонкої плівки виготовленої методом електронно-променевого випаровування (рис. 1б) гладка і без видимих отворів, що має вирішальне значення для створення якісних $\mathrm{i}$ стабільних електронних приладів з високим коефіцієнтом випрямлення та високою фоточутливістю. Товщина досліджуваної тонкої плівки становила близько 30 нм, що добре узгоджується 3 даними, отриманими за допомогою контролера осадження INFICON XTC.

Спектри раманівського розсіювання для поверхні тонких плівок графіту отриманих двома різними методами наведено на рис. 2. Відомо, що в однофононних раманівських спектрах досконалих монокристалів графіту спостерігається одна вузька лінія $G$ при $1580 \mathrm{~cm}^{-1}$, відповідальними за яку є симетричні $E_{2 g}$ коливання розтягування - стискування $s p^{2}$-зв'язків С-C в 6-атомних ароматичних графенових шарах [10].
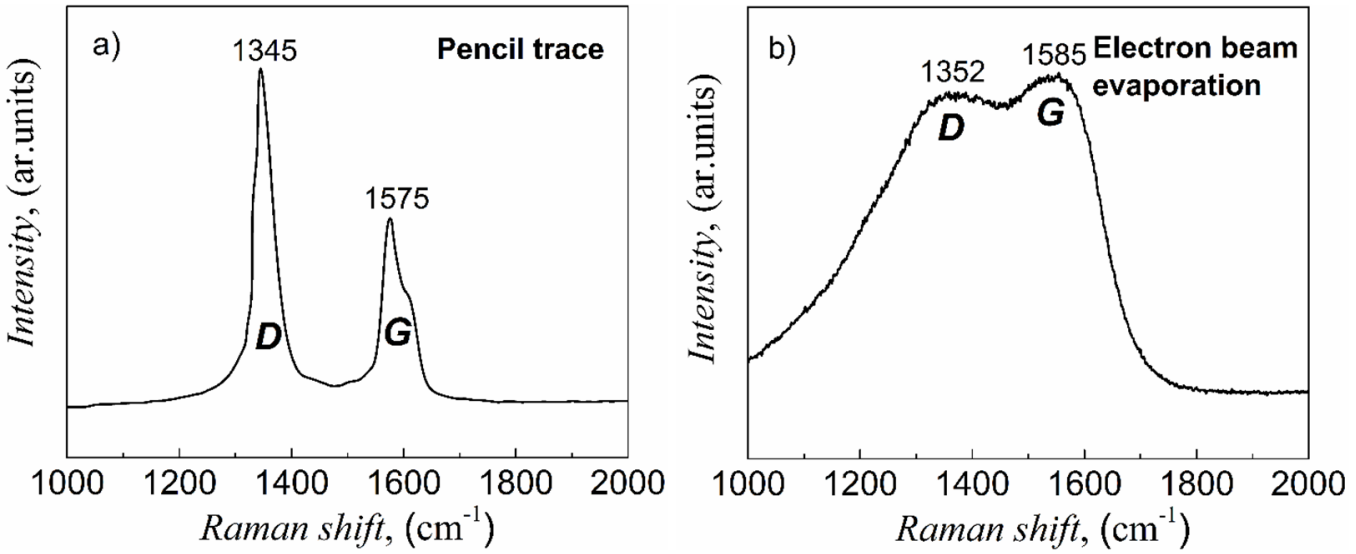

Рис. 2. Раманівські спектри тонких плівок графіту виготовлених різними методами

а) - нарисована плівка графіту, б) - плівка виготовлена методом електронно-променевого випаровування

При дробленні монокристалів графіту до мікро- або нанокристалітів у нанокристалах графіту виявляються можливими раманівські переходи за участю фононів в околі точки $K$ зони Бріллюена, внаслідок чого в спектрах поблизу $1350 \mathrm{~cm}^{-1}$ з'являється відома смуга $D$ [10], тому смуга $D$ може служити індикатором присутності у вуглецевій структурі графітоподібних кластерів [11].

На відміну від смуги $D$ смуга $G$ спостерігається при будь-якій організації зв’язків вуглецю, включаючи всі можливі кільця і ланцюги, в тому числі і розупорядковані.

Варто відмітити, що $G$ смуга на спектрах раманівського розсіювання (рис. 2) для нарисованих плівок графіту та для плівок отриманих електронно-променевим випаровуванням корелює 3 раманівським спектром високоорієнтованого піролітичного графіту [12], а яскраво виражена $D$ смуга, походить від невпорядкованої структури нарисованих олівцем графітових плівок, які були відпалені при 920 К (рис. 2а) та плівок отриманих електронно променевим випаровуванням (рис. 2б). Наявність більш розмитих піків на спектрах раманівського розсіювання для плівки отриманої методом електронно променевого випаровування (рис. 2б) свідчить про те, що тонка плівка отримана таким методом є полікристалічною і володіє меншим розміром зерен в порівнянні з нарисованою плівкою.

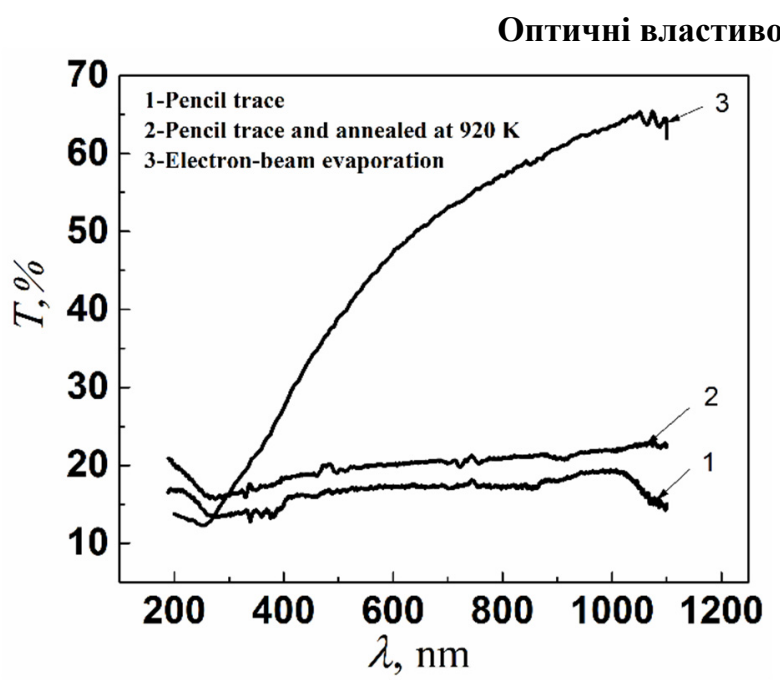

Рис. 3. Спектри пропускання тонких плівок графіту, виготовлених різними методами
На рис. 3 зображено спектри пропускання тонких плівок графіту, для трьох графітових плівок, які були виготовлені двома методами: “олівець-нанапівпровіднику” та методом електронно-променевого випаровування, після чого одна 3 нарисованих плівок була відпалена при температурі 920 К.

3 рисунка бачимо, що відпал призвів до зростання пропускання. Це обумовлено покращенням структурної досконалості плівок в процесі відпалу. Пропускання для тонких плівок отриманих методом електронно-променевого випаровування $\epsilon$ найвищим в порівнянні 3 нарисованими плівками, що обумовлено їх найменшою товщиною $\left(\mathrm{d}_{\text {ел-про }}=30 \mathrm{HM}\right.$, $\left.\mathrm{d}_{\text {нарисована }}=150 \mathrm{HM}\right) . \quad$ Мінімальні значення пропускання при 250 нм пояснюються розсіюванням світла на дефектах, які утворюються на границях зерен [13]. 


\section{Електричні властивості тонких плівок графіту}

Результати вимірювання температурної залежності електричного опору досліджуваних тонких плівок графіту представлені на рисунку 4а показали, що опір зменшується при зростанні температури, що вказує на напівпровідниковий тип провідності.
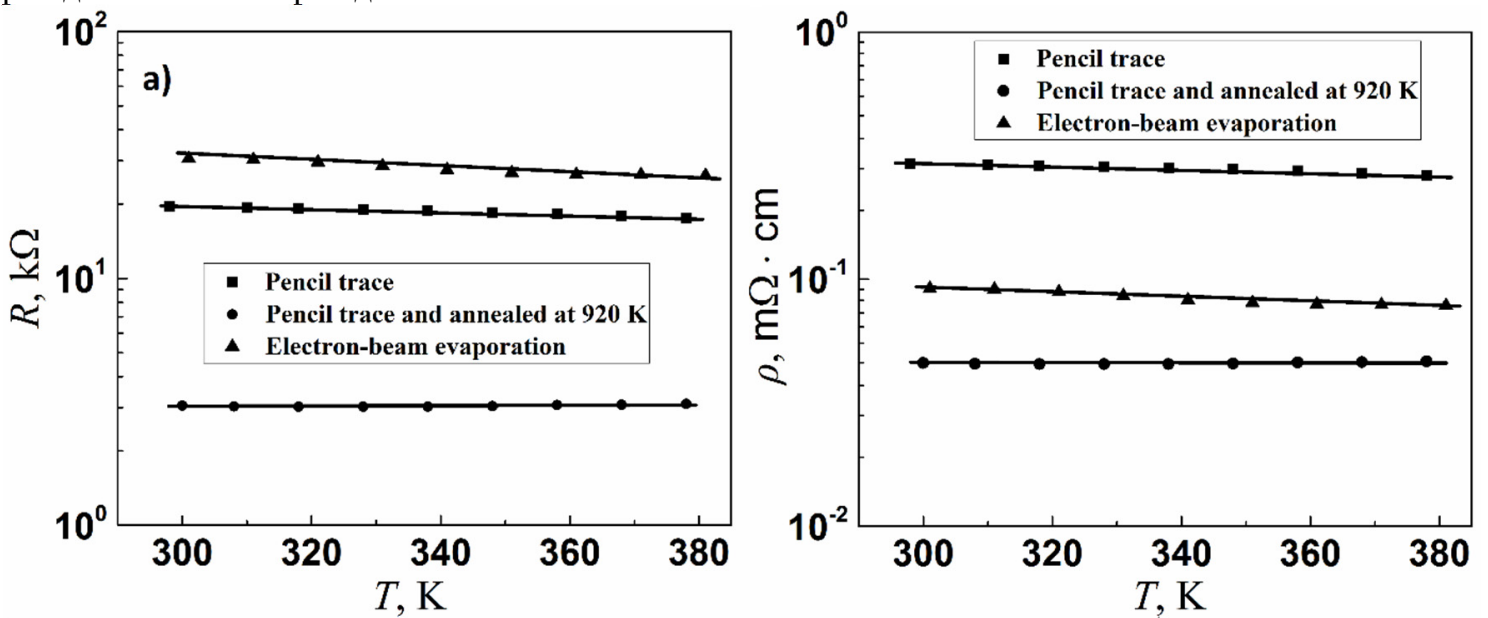

Рис. 4. Температурні залежності опору тонких плівок графіту виготовлених різними методами а) - електричного опору, б) - питомого опору

Із залежності питомого опору від температури показаної на рисунку 4,б видно, що нарисовані плівки графіту володіють вищим питомим опором ніж плівки отримані електронно-променевим випаровуванням, але відпал нарисованих плівок графіту привів до зменшення питомого опору, що відбулося через покращення їх структурної досконалості, а як наслідок отримали найменші значення питомого опору.

Відомо, що границі зерен у графіті і графітоподібних матеріалах суттєво впливають на фізичні властивості матеріалу [14]. Електричне поле зарядів на границі зерен утворює енергетичні бар'єри $E_{b}$ для руху носіїв заряду. Між кристалітами утворюються області товщиною $\delta$, які збіднені на основні носії заряду.

Сумарний струм крізь полікристалічний матеріал визначається як провідністю зерен[15], так і механізмом переходу носіїв заряду з одного кристаліта в інший[16-18], тобто провідністю міжзеренних границь. Провідність зерен суттєво більша за провідність границь. Через це при вивченні руху носіїв заряду у полікристалічних плівках в першу чергу слід розглядати провідність областей між кристалітами[19,20]. Провідність полікристалічних плівок $\sigma$ з врахуванням енергетичних бар'єрів на межі зерен, описується виразом:

$$
\sigma=\frac{L q^{2} n}{\sqrt{2 \pi m^{*} k T}} \exp \left(-\frac{q V_{b}}{k T}\right)
$$

де $L$ - середній розмір кристалітів; $m^{*}$ - ефективна маса носіїв заряду; $n$ - концентрація носіїв заряду всередині кристаліта; $q V_{b}=E_{b}-$ висота потенціального бар'єра на границі зерен.

Для визначення висоти потенціальних бар'єрів $E_{b}$ на границях зерен у графітизованих тонких плівках вуглецю була використана температурна залежність електропровідності у діапазоні $300 \mathrm{~K}<T<380$ К побудована у напівлогарифмічних координатах $\ln \left(\sigma \cdot T^{1 / 2}\right)=f\left(10^{3} / T\right)$ (рис. 6.)

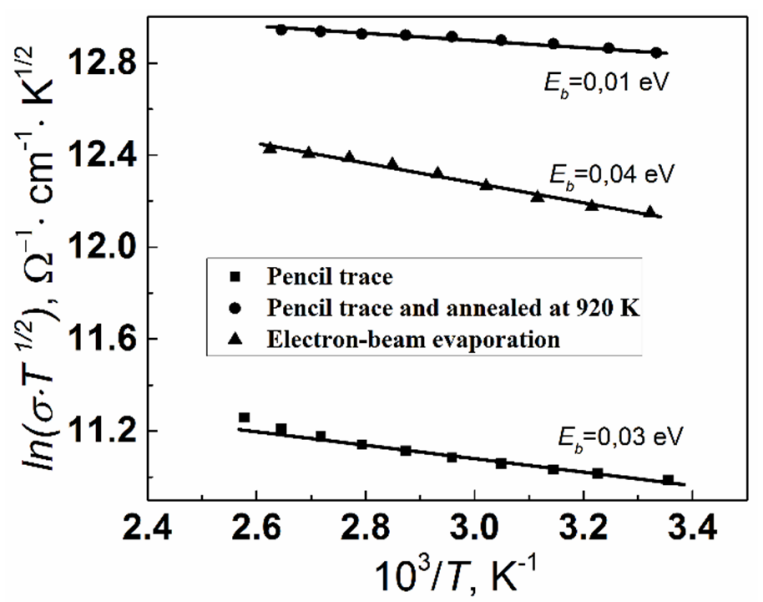

Рис. 6. Температурні залежності електропровідності плівок графіту, отриманих різними методами 
Висота потенціального бар'єра на границях зерен для нарисованих плівок графіту становить $E_{b}=0,03$ еВ, для відпаленої $E_{b}=0,01 \mathrm{eB}$ та для тонких плівок графіту виготовлених електронно-променевим випаровуванням $E_{b}=0,04$ еВ. Видно, що для відпаленої плівки висота потенціального бар`єра $\epsilon$ найменшою.

\section{ВИСНОВКИ}

Досліджено структурні властивості двох тонких плівкок графіту, а саме: нарисованої плівки графіту та відпаленої при 920 К та отриманої методом електронно-променевого випаровування при температурі підкладки 920 К. Згідно результатів СЕМ структурно досконаліші плівки графіту отримані електронно-променевим осадженням, а наявність більш розмитих піків на спектрах раманівського розсіювання для плівки, отриманої методом електронно-променевого випаровування, свідчить про те, що тонка плівка отримана таким методом $є$ полікристалічною і володіє меншим розміром зерен в порівнянні з нарисованою плівкою.

Досліджено вплив відпалу на нарисовані плівки графіту: їх оптичні та електричні властивості до і після термообробки.

Показано, що плівки графіту отримані методом електронно-променевого випаровування володіють найвищим пропусканням $\left(T_{550} \approx 60 \%\right)$, а пропускання нарисованих плівок $\epsilon$ найменшим, відпал приводить до його зростання. Мінімальні значення пропускання при довжині хвилі $\lambda=250$ нм обумовлені розсіюванням світла на дефектах, які утворюються на границях зерен.

Встановлено, що тонкі плівки графіту володіють стрибковою провідністю з енергетичними бар'єрами для невідпаленої $E_{b}=0,03 \mathrm{eB}$, для відпаленої $E_{b}=0,01 \mathrm{eB}$ та для виготовленої електронно-променевим методом $E_{b}=0,04 \mathrm{eB}$.

Встановлено, що відпалені плівки графіту володіють найкращою структурною досконалістю оскільки вони мають найменший питомий опір, в порівнянні з невідпаленими плівками та плівками отриманими електроннопроменевим методом та володіють найменшою висотою потенціального бар'єра. Одночасне збільшення пропускання у всьому спектральному діапазоні, підвищення питомої електричної провідності та пониження потенціального бар'єра на границях кристалітів відпаленої нарисованої плівки графіту чітко свідчить про упорядкування нарисованих пластівців графіту, перенесених на нову підкладку, що привело до зменшення розсіювання світла та покращення умов струмопереносу між пластівцями графіту за рахунок більшої площі перекриття між ними.

Встановлено, що відпалені плівки графіту не поступаються електричними властивостями, а $є$ навіть кращими від плівок напилених методом електронно-променевого випаровування. Метод «олівець-нанапівпровіднику» $є$ більш екологічним і дешевшим, тому виготовлення тонких плівок графіту даним методом $\epsilon$ актуальним.

\section{ORCID IDs}

(D)Mykhailo M. Solovan, https://orcid.org/0000-0002-1077-5702; (DViktor V. Brus, https://orcid.org/0000-0002-8839-124X, DPavlo D. Maryanchuk, https://orcid.org/0000-0002-5523-4280

\section{СПИСОК ЛІТЕРАТУРИ}

[1] E. Rollings, G.-H. Gweon, S.Y. Zhou, B.S. Mun, J.L. McChesney, B.S. Hussain, A.V. Fedorov, P.N. First, W.A. de Heer, and A. Lanzara, J. Phys. Chem. Sol. 67, 2172 (2006), https://doi.org/10.1016/j.jpcs.2006.05.010.

[2] S. Tongay, T. Schumann, X. Miao, B.R. Appleton, and A.F. Hebard, Carbon, 49, 2033 (2011), https://doi.org/10.1016/j.carbon.2011.01.029.

[3] V.V. Brus, and P.D. Maryanchuk, Carbon, 78, 613-616 (2014), https://doi.org/10.1016/j.carbon.2014.07.021.

[4] M. Murakami, A. Tatami, and M. Tachibana, Carbon. 145, 23-30 (2019), https://doi.org/10.1016/j.carbon.2018.12.057.

[5] Q. Zheng, P.V. Braun, and D. G. Cahill, Adv. Mater. Interfaces. 3, 1600234 (2016), https://doi.org/10.1002/admi.201600234.

[6] V.V. Brus and P.D. Maryanchuk, Applied Physics Letters, 104, 173501 (2014), https://doi.org/10.1063/1.4872467.

[7] M.M. Solovan, H.P. Parkhomenko, and P.D. Marianchuk, Journal of Physical Studies, 23, 4801 (2019), https://doi.org/10.30970/jps.23.4801.

[8] S.M. Sze, and K. Kwok, Physics of Semiconductor Devices, (Wiley, New Jersey, 2007), pp. 832.

[9] B.L. Sharma, and R.K. Purohit, Semiconductor hetero-junctions, (Pergamon, 1974).

[10] A.C. Ferrari, and J. Robertson, Phys. Rev. B, 61, 14095 (2000), https://doi.org/10.1103/PhysRevB.61.14095.

[11] É.A. Smorgonskaya, and V.I. Ivanov-Omskii, Semiconductors, 39, 934 (2005), https://doi.org/10.1134/1.2010688.

[12] T. Kaplas, and P. Kuzhir, Nanoscale Res. Lett. 11, 54 (2016), https://doi.org/10.1186/s11671-016-1283-2.

[13] V.V. Brus, M. Gluba, J. Rappich, F. Lang, P.D. Maryanchuk, and N.H. Nickel, ACS Applied Materials and Interfaces. 10, 4737 (2018), https://doi.org/10.1021/acsami.7b17491.

[14] V.V. Brus, M. Ilashchuk, I. Orletskyi, M. Solovan, G. Parkhomenko, I.S. Babichuk, N. Schopp, G.O. Andrushchak, A. Ostovyi, and P. D Maryanchuk, Nanotechnology, 31, 505706 (2020) https://doi.org/10.1088/1361-6528/abb5d4.

[15] G. Lormand, Journal de Physique Colloques, 43 (C6), C6-283 (1982), https://doi.org/10.1051/jphyscol:1982625.

[16] A. Tschöpe, and R. Birringer, Journal of Electroceramics, 7, 169 (2001), https://doi.org/10.1023/A:1014483028210.

[17] V.H. Nguyen, U. Gottlieb, A. Valla, D. Muñoz, D. Belleta, and D. Muñoz-Rojas, Mater. Horiz. 5, 715 (2018), https://doi.org/10.1039/C8MH00402A.

[18] H.-S. Kim, S.D. Kang, Y. Tang, R. Hanus, and G.J. Snyder, Mater. Horiz. 3, 234 (2016), https://doi.org/10.1039/C5MH00299K.

[19] C.H. Seager, and G.E. Pike, Appl. Phys. Lett. 40, 471 (1982).

[20] P. Forsyth, R. King, G. Metcalfe, and B. Chalmers, Nature, 158, 875 (1946), https://doi.org/10.1038/158875a0. 


\section{ОПТИЧНІ І ЕЛЕКТРИЧНІ ВЛАСТИВОСТІ ТОНКИХ ПЛІВОК ГРАФІТУ ОТРИМАНИХ РІЗНИМИ МЕТОДАМИ М.М. Солован ${ }^{\mathrm{a}}$, Г.М. Ямрозик ${ }^{\mathrm{a}}$, В.В Брус ${ }^{\mathrm{b}}$, П.Д. Мар'янчука \\ ачернівецький національний університет імені Юрія Федьковича вул. Кочюбинського 2, 58012 Чернівиі, Україна \\ ${ }^{b}$ Університет імені Назарбаева, 53, Қабанбай батир, 010000, Нур-Султан, Казахстан}

У роботі представлено результати досліджень структурних, оптичних і електричних властивостей тонких плівок графіту виготовлених двома методами, а саме: безвакуумним методом «Олівець-на-напівпровіднику» та методом електроннопроменевого випаровування, такі дослідження мають велике значення для подальшої розробки високоефективних приладів на основі гетеропереходів для електроніки і оптоелектроніки. Виготовлені безвакуумним методом тонкі плівки графіту були відпалені при температурі 920 К. Виміряні спектри пропускання досліджуваних графітових плівок при $\mathrm{T}=300 \mathrm{~K}$ та електричні властивості тонких плівок, визначено значення висоти потенціальних бар'єрів $E_{b}$ на границях зерен, для цього була використана температурна залежність електропровідності у діапазоні $300 \mathrm{~K}<T<380 \mathrm{~K}$ побудована у координатах $\ln \left(\sigma \cdot T^{1 / 2}\right)=f\left(10^{3} / T\right)$. Встановлено, що висота бар'єра на границях зерен для нарисованих плівок графіту становить $E_{b}=0,03 \mathrm{eB}$, відпаленої - $E_{b}=0,01 \mathrm{eB}$ та для тонких плівок графіту виготовлених електронно-променевим випаровуванням $E_{b}=0,04 \mathrm{eB}$, тобто для відпаленої плівки висота потенціального бар`єра є найменшою. Показано, що плівки графіту отримані методом електронно-променевого випаровування володіють найвищим пропусканням (Т550 $\approx 60 \%)$, а пропускання нарисованих плівок $є$ найменшим, відпал призводить до його зростання. Мінімальні значення пропускання при довжині хвилі $\lambda=250$ нм обумовлені розсіюванням світла на дефектах, які утворюються на границях зерен. Встановлено, що відпалені плівки графіту володіють найкращою структурною досконалістю оскільки вони мають найменший питомий опір, в порівнянні 3 невідпаленими плівками та плівками отриманими електронно-променевим методом та володіють найменшою висотою потенціального бар'єра. Одночасне збільшення пропускання у всьому спектральному діапазоні, підвищення питомої електричної провідності та зниження потенціального бар'єру на границях кристалітів відпаленої нарисованої плівки графіту чітко свідчить про упорядкування нарисованих пластівців графіту, перенесених на нову підкладку, що привело до зменшення розсіювання світла та покращення умов струмопереносу між пластівцями графіту за рахунок більшої площі перекриття між ними.

КЛЮЧОВІ СЛОВА: «олівець-на-напівпровіднику», відпал, тонкі плівки, графіт, границі зерен

\section{ОПТИЧЕСКИЕ И ЭЛЕКТРИЧЕСКИЕ СВОЙСТВА ТОНКИХ ПЛЕНОК ГРАФИТА ПОЛУЧЕНЫХ РАЗНЫМИ МЕТОДАМИ}

М.Н. Солован ${ }^{\mathrm{a}}$, Г.Н. Ямрозык

ачерновичкий национальный университет имени Юрия Федьковича ул. Кочюбинского 2, 58012 Черновиы, Украина

${ }^{b}$ Университет имени Назарбаева, 53, Қабанбай батыр, 010000, Нур-Султан, Казахстан

В работе представлены результаты исследований структурных, оптических и электрических свойств тонких пленок графита изготовленных двумя методами: а именно безвакуумным методом «карандаш-на-полупроводнике» и методом электроннолучевого испарения, такие исследования имеют большое значение для дальнейшей разработки высокоэффективных приборов на основе гетеропереходов для электроники и оптоэлектроники. Полученные безвакуумным методом тонкие пленки графита были отожжены при температуре 920 К. Измерены спектры пропускания исследуемых графитовых пленок при T = 300 К и электрические свойства тонких пленок, определено значение высоты потенциальных барьеров $E_{b}$ на границах зерен, для этого была использована температурная зависимость электропроводности в диапазоне $300 \mathrm{~K}<\mathrm{T}<380$ К построенная в координатах $\ln \left(\sigma \cdot T^{1 / 2}\right)=f\left(10^{3} / T\right)$. Установлено, что высота барьера на границах зерен нарисованной пленки графита составляет $E_{b}=0,03 \mathrm{eB}$, для отожженной $E_{b}=0,01 \mathrm{eB}$ и для тонких пленок графита изготовленных электронно-лучевым испарением $E_{b}=0,04 \mathrm{eB}$, то есть для отожженной пленки высота потенциального барьера является наименьшей. Показано, что пленки графита, полученные методом электронно-лучевого испарения, обладают высоким пропусканием (Т550 $\approx 60$ \%), а пропускание нарисованных пленок является наименьшим, отжиг приводит к его росту. Минимальные значения пропускания при длине волны $\lambda=250$ нм обусловлены рассеянием света на дефектах, которые образуются на границах зерен. Установлено, что отожженные пленки графита обладают лучшим структурным совершенством поскольку они имеют наименьшее удельное сопротивление, по сравнению с не отожжёнными пленками и пленками, полученными электронно-лучевым методом, и обладают наименьшей высотой потенциального барьера. Одновременное увеличение пропускания во всем спектральном диапазоне, повышение удельной электрической проводимости и понижение потенциального барьера на границах кристаллитов отожженной нарисованной пленки графита четко свидетельствует об упорядочении нарисованных хлопьев графита, перенесенных на новую подложку, что привело к уменьшению рассеяния света и улучшению условий токопереноса между хлопьями графита за счет большей площади перекрытия между ними.

КЛЮЧЕВЫЕ СЛОВА: «карандаш-на-полупроводнике», отжиг, тонкие пленки, графит, границы зерен 